\title{
Perceived Effective Entrepreneurship Education and Entrepreneurial Intention: The Role of the Perception of University Support and Perceived Creativity Disposition
}

\author{
Yeng Keat, Ooi and Abdullahi, Nasiru \\ Universiti Utara Malaysia, Kedah, Malaysia \\ ykooi@uum.edu.my
}

\begin{abstract}
In order to increase our understanding of the factors that underlie entrepreneurial intention formation, this article investigates the roles of individual creativity disposition and the perception of university support. The study considers how the personal characteristic may mediate students' perception of effectiveness of entrepreneurship education and entrepreneurial intention. The study also aims to determine the perception of university support that could moderate the relationship between perception of the effectiveness of entrepreneurship education and creativity disposition. Using a survey of 158 university students and employing Structural Equation Modelling (SEM) with AMOS version 22, the results show that perceived creativity disposition facilitate our understanding on the entrepreneurship education and entrepreneurial intention relationship. However, in our analysis, university support does not invigorate the role of entrepreneurship education in enhancing perceived creativity disposition. Implications for research and practice are provided.
\end{abstract}

Keywords: Entrepreneurial intention, perceived effectiveness of entrepreneurship education, perceived creativity disposition and perception of university support

\section{Introduction}

As a prerequisite to new venture formation entrepreneurial intention is continually receiving increasing attention, most especially from a social psychological viewpoint (Edelman \& Yli-Renko, 2010; Krueger Jr, Reilly, \& Carsrud, 2000; Shapero \& Sokol, 1982; Shook, Priem, \& McGee, 2003). Entrepreneurial intention is an important factor for providing good predictive power for engaging in entrepreneurship (Ajzen, 1987; Brush, Manolova, \& Edelman, 2008; Kolvereid \& Isaksen, 2006; Shook et al., 2003). Earlier contributions show that intentions have the ability to predict both individual behaviours (Ajzen, 1991), and organizational results in terms of survival, development and growth (Mitchel, 1981). Consequently, managers and entrepreneurs are appreciating and predicting intentions as an important element to succeed (Tubbs \& Ekeberg, 1991). Even though some ventures are commenced for solving some problems of need and then growing to serve a bigger market, many are as a result of a planned process (Ajzen, 1987; Bird, 1988; Edelman \& Yli-Renko, 2010; Kautonen, Luoto, \& Tornikoski, 2010; Krueger Jr et al., 2000; Lee, Wong, Foo, \& Leung, 2011; Shapero \& Sokol, 1982). According to some scholars' entrepreneurial intention is the interest to undertake entrepreneurial activity (Fitzsimmons \& Douglas, 2011; Gurbuz \& Aykol, 2008; Krueger Jr et al., 2000), which usually involves inner guts, desire and the feeling to be independent (Ayobami \& Ofoegbu, 2011). As a result, entrepreneurial intention can be employed to envisage participation among students in entrepreneurship and could clarify the reason for students' decision to venture into business (Ariff, Bidin, Sharif, \& Ahmad, 2010). Understand the real factors responsible for shaping intention of students' to start a new venture is crucial for building the programmes and policies aim at promoting entrepreneurial behaviour (Bakotić \& Kružić, 2010).

It is also important that potential entrepreneurs are identified and developed at their early stage while in school (Chen \& Lai, 2010), while, instructors must understand the factors that motivate or hinder entrepreneurial activity (Tajeddini \& Mueller, 2009). In order to design effective programmes, the factors that influence students' career choice towards self-employment should be identified; since good understanding of these factors are useful for encouraging entrepreneurial behaviour and entrepreneurial success (Lüthje \& Franke, 2003). Thus, individual entrepreneurial intention will possibly remain an important construct in research area involving enterprising persons, their recognition of business opportunities and the choice to 
exploit various risks in establishing new ventures (Palich \& Ray Bagby, 1995). In prior study, personal and environment determinants of entrepreneurial intention such as attitudes toward entrepreneurship, personality traits and social environment are widely discussed (Brandstätter, 1997; Davidsson, 1995; Franke \& Lüthje, 2004; Robinson \& Haynes, 1991; Segal, Borgia \& Schoenfeld, 2005). Accordingly, entrepreneurial potential will motivate individuals if they believe they poses the ability, the environmental hold some potentialities and there are available social support (Kirby, 2006). The motivation to achieve and self-image have equally become known as key contributing factors (de Pillis \& Reardon, 2007). Other scholars, studying the role of contextual dimensions, indicate that environmental influences (Morris \& Lewis, 1995) and environmental support (Lüthje \& Franke, 2003) impact entrepreneurial intentions.

In order to extend the literature in entrepreneurship study, this study investigates the interplay among effectiveness of entrepreneurship education and individual characteristic as well as environmental support that have received less attention in entrepreneurship research: perceived creativity disposition and perception of university support. Hence, the principal research question that drives this study is how the perception of university support might affect the potency with which student's perceived effectiveness of entrepreneurship education, will inform the perception of creativity disposition on one hand, and how the perception of their creativity disposition on the other hand will explain why the student's perception of effectiveness of the entrepreneurship education, will inform entrepreneurial intention. Thus, our contribution is in the following direction; that by examining the influence of individual students' creativity disposition on entrepreneurial intentions, we address an important factor that has hardly been considered in intention based models (Hamidi, Wennberg, \& Berglund, 2008).It is also believe that the important factors of personality and good supporting environment could influence a person's creative ability (Fritsch \& Sorgner, 2013), so, training becomes a focal point for creative ability enhancement (Cropley \& Cropley, 2000), which this study consider the university to deliver in that direction. Furthermore, this study will clarify more on the interplay among both personal and contextual/environmental factors, as little is known about the interaction between university environment and personality or other factors said to influence entrepreneurial intention (Schwarz, Wdowiak, Almer-Jarz, \& Breitenecker, 2009).

\section{Literature Review and Hypothesis Development}

Entrepreneurship education and creativity: Entrepreneurial education has been defined by Jones and English (2004) as a way of developing individuals' ability to recognise business opportunities and cash on them, to develop self-esteem and to develop knowledge and skills in commencing a business venture in the event of risk. Their definition however, emphasize on the kind of knowledge that is action based, encouraging practical learning, problem-solving type, project based, creative and allowing peer evaluation. They further argued that such learning process offers enterprising skill behaviour that is required to create and manage ventures. Similarly, this study conceptualize effective entrepreneurship education as that which provides individuals with practical sense of business, building self-confidence and developing skill for a successful business venture (Wilson, Kickul, \& Marlino, 2007). It is understood from history that educational process design has certain implications for the capabilities of individuals engaged in innovative activities (Baumol, 2004). Baumol (2004) went further to explain that education on one hand provide to future entrepreneurs analytical tools necessary for engaging in innovative related activities, and on the other hand encouraged creativity and imagination in a simplified manner. Hence, it is generally agreed that creativity is a skilled that can be learned (Runco, 2004) and taught through support activities, encouragement and support to individuals (Williamson, 2001). Literature has also shown that creativity and innovation capacity can only be enhanced through continually generating knowledge and its applications (Williamson, 2001), hence, the strong dependency between the creation of knowledge and creativity (Chen, Hu, Wang, \& Chen, 2011). Studies in the past have also long indicated that education should emphasize the development of creativity, believing creativity can be so influenced, and hence so many kinds of training programmes have been suggested to develop creative thought processes (Craft, 2001). In addition, creativity training programmes available in schools are said to be more effective with high involvement of teachers (Benjamin, 1984).

In a report by Tepper and Kuh (2011), the authors believe that creativity can be nurtured by training and developing specific skill over time. Hence, effective enterprise/entrepreneurship education must develop enterprising skills (Pittaway, Hannon, Gibb, \& Thompson, 2009) and the key enterprising skill is the creative 
thinking (Gibb, 2002; A. A. Gibb, 1993). That is why creativity development among students in business schools has become a matter of priority (Ghosh, 2014). DeTienne and Chandler (2004) asserted that creativity enhancing training was found to significantly improve university students' ability to think creatively. In addition, Feng (2013), emphasised that education in creativity increases students creative ability; enhance their problem-solving ability and their discipline aptitude. Consequent to past literatures' emphases that entrepreneurial education is vital in increasing creativity development in people, especially the effectiveness of the programme, this study proposed the following hypothesis:

H1: Perceived effective entrepreneurship education is positively related to perceived creativity disposition

Creativity and entrepreneurial intention: Creativity is defined as creating something that is novel and useful (Amabile, 1996). it is also regarded and conceptually accepted in this study as the combination and rearrangement of knowledge in the minds of people that allows flexible thinking in the creation of the novel ideas that are unexpected but rather useful (Chen, Li, Li, Zhang, \& Dong, 2013). Godfrey (1996) Considers creativity necessary for continuing reinventing businesses and suggests unleashing imagination of people through playfulness and fun. He also considers innovation as necessary to turn ideas into goods and services that are useful and beneficial to the market. Creativity, thus, is the basis of innovation (Almog-Bareket, 2011; Dewett \& Gruys, 2007) and key to organizational growth. Hamidi, Wennberg \& Berglund (2008) employed social cognitive theory to clearly indicate the need for considering creativity in entrepreneurial intention based models. The researcher believe strongly that creativity disposition will built enormous amount of confidence that is very likely to yield expected result of becoming self-employed. In a related study, Zampetakis, Gotsi, Andriopoulos and Moustakis (2011) shows that the more creative the students think they are, the higher their entrepreneurial intentions. Furthermore, Fatoki (2010) identified in a study of entrepreneurial intention of south African final year graduating students that creativity was a motivator of entrepreneurial intention. Moreover, several studies have supported self-assessment of creativity disposition, for example, Batey \& Furnham (2008) argue that individuals understand themselves better when it comes to their own creative ability. Therefore, people should be allowed to make effort to judge themselves as capable of generating new and valuable ideas necessary to succeed as entrepreneurs (Darini, Pazhouhesh, \& Moshiri, 2011). This study will therefore investigate further the influence of individual students creativity disposition on entrepreneurial intentions, which has hardly been considered in intention based models (Hamidi et al., 2008). Hence, the following hypothesis is proposed:

H2: Perceived creativity disposition is positively related to entrepreneurial intention

University support and entrepreneurial intention: As Drucker (1993) relates, what makes entrepreneurship effective may not be economical, but changes that are institutional. Universities are therefore seen as promoters of entrepreneurship by providing entrepreneurship education and complimentary supports that are necessary to boost the potential intentions of venture creation and subsequent growth, hence they are key players in the provision of training (OECD, 2010; Romero, Petrescu, \& Balalia, 2011). When high quality entrepreneurship programmes are delivered, then higher number of entrepreneurs will emerge (Wang \& Verzat, 2011). Accordingly the university environment is the right place to mould and influence students to build entrepreneurial intention (Franke \& Lüthje, 2004). Therefore, environmental perception guides individual behaviour (OECD, 2010). For example, Luthje and Franke (2003)showed that barriers and support factors in the entrepreneurship setting directly affects entrepreneurial intention. Similarly, Turker and Selcuk (2009) indicated that educational and structural supports have impact on entrepreneurial intention of students. Hence, in their quest to determine the essential factors influencing students' intention to create new venture, Schwarz et al. (2009) found university environment as influencing students' entrepreneurial intention. Accordingly, universities play significant role in entrepreneurial curriculum and content development as well as making entrepreneurship appealing to students (Keat, Selvarajah, \& Meyer, 2011; Wang \& Verzat, 2011). Following these findings, the hypothesis is developed:

H3. Perception of university support is positively related to entrepreneurial intention

The mediating role of perceived creativity disposition: We argue that perceived creativity disposition will explain the relationship between the perceived effectiveness of entrepreneurship education and entrepreneurial intention. Entrepreneurship programmes is shown to increases attitudes and the overall entrepreneurial intention (Souitaris, Zerbinati, \& Al-Laham, 2007). Also, Dohse and Walter (2010) revealed 
that intentions and attitudes are directly affected by the active modes of entrepreneurship education, while the influence of the reflective modes depends on the environmental area. Hence the study provides implication for delivering of entrepreneurship education. More literature has also established a considerable change in perception and the positiveness as a result of the experience obtained from the enterprise education program (Peterman \& Kennedy, 2003). Other results revealed considerable changes in attitudes in response to entrepreneurship education (Byabashaija \& Katono, 2011). The findings present lessons for policy makers and raise more questions for researchers, probably on how effective such courses in entrepreneurship education can be and the mechanism that can explain its effectiveness. Zainuddin and Rejab (2010) also believed that specialized entrepreneurship education contributes to increasing entrepreneurial self-efficacy and subsequently towards their self-employment intention, and therefore increases their employability value. This study therefore highlighted that, introducing specific entrepreneurship education targeted and suitable to a particular group could yield a desire result. Hence, the following hypothesis is formulated:

H4. Perceived creativity disposition mediates the positive relationship between perceived effective entrepreneurship education and entrepreneurial intention

The moderating role of the perception of university support: In addition, we argue that perception of university support amplifies the positive relationship between perceived effective entrepreneurship education and perceived creativity disposition. Personality traits are said to lose their strength in affecting entrepreneurial intentions because individuals are operating within a particular environmental situation that may be responsible for the weak efficacy of personality characteristics (Franke \& Lüthje, 2004; Schwarz et al., 2009). According to Bechard \& Toulouse (1998) what is responsible for influencing students' decision to become entrepreneurs are embedded in the universities. In affirmation, Franke and Luthje (2004) emphasised that universities do have control over some factors that can enhance students' entrepreneurial intentions; they initiate entrepreneurial spirit by arranging and providing a conducive, creative and supportive atmosphere that is necessary for imaginative thinking that is useful and applicable. Moreover, entrepreneurship career development can be supported by universities (Turker \& Selcuk, 2009) by employing role models in training, providing entrepreneurial support network and encouraging business plan competitions among students (Lüthje \& Franke, 2003). Other studies have also shown the relevance of some factors in developing entrepreneurship, some of which are; environmental culture, established dedicated facilities meant for entrepreneurship related activities and other resources to aid idea generation and innovation among students (Autio, Keeley, Klofsten, \& Ulfstedt, 1997; Fayolle, 2000). In a qualitative study Maina (2011) examined the role of colleges in influencing entrepreneurial intentions among young people. The study found that the college environment and exposure to entrepreneurship experiences impacted on entrepreneurial intentions by impacting on self-efficacy and perceptions of desirability. A study by Ayob, Hussain, Mustafa, \& Shaarani (2011) concluded that supportive learning environment is capable of developing creativity. While, other important factors of personality and good supporting environment could also influence a person's creative ability (Fritsch \& Sorgner, 2013). Based on these assertions, we proposed the following hypothesis:

H5. An increase in the perception of university support will strengthen the positive relationship between perceived effective entrepreneurship education and perceived creativity disposition, such that the relationship is amplified for a stronger perception of university support.

\section{Methodology}

Sample and data collection: The hypotheses of the study were tested with quantitative data obtained from a sample of university. Since our focus is on the entrepreneurial intentions, university students are ideally suited for the study as they are yet to perform the actual entrepreneurial behaviours (Krueger Jr et al., 2000). Students cutting across various academic backgrounds (e.g. social sciences, humanities, sciences) and those whom have offered or are offering the entrepreneurship education as a course from Bayero University Kano in Nigeria completed the self-administered survey questionnaires. The university's entrepreneurship coordinators employed the service of the entrepreneurship education course lecturers to distribute and collect the questionnaires. The final sample consisted of 158 respondents. 


\section{Construct measures}

Effective entrepreneurship Education: This section adapted 5 items with a 7-point Likert-scales of 1= strongly disagree to $7=$ strongly agree to measure perception of the effectiveness of entrepreneurship education from Souitaris et al. (2007). These items were initially developed as a perceptual scale to measure learning. Example of the questions are; "to what extent did the entrepreneurship education increase your understanding of the attitudes, values and motivation of entrepreneurs"?, "to what extent did the entrepreneurship education increase your understanding of the actions someone has to take in order to start a business"? $(\alpha=.84)$.

Perceive Creativity Disposition: The perception of creativity disposition is measured by using 8 items that is adapted from Zhou and George (2001). This construct is employed in order to assess students' perception of their capability of producing novel and useful ideas. Examples of the items are: "I come up with creative solutions to problems", "I am a good source of creative ideas" and etc. $(\alpha=.87)$.

Perception of University Support: The measurement for the perceived university support is adapted from Autio et al. (1997). The instrument consists of 4 items and the example of the items included: "The courses provide students with the knowledge required to start a new company" $(\alpha=.81)$.

Entrepreneurial Intention: The 6 items measuring entrepreneurial intention is adapted from Linan and Chen (2009). Some of the sample items are: "I am ready to do anything to be an entrepreneur", "I am determined to create a firm in the future" and etc. $(\alpha=.88)$.

\section{Structural Model}

Creating Composites from factor scores: Composite variables were created from the factor score in AMOS; this was to avoid using the full structural model with all the individual items attached (see figure1). The interaction terms were computed by multiplying the standardized variables of interest.

\section{Figure 1: Structural Model}

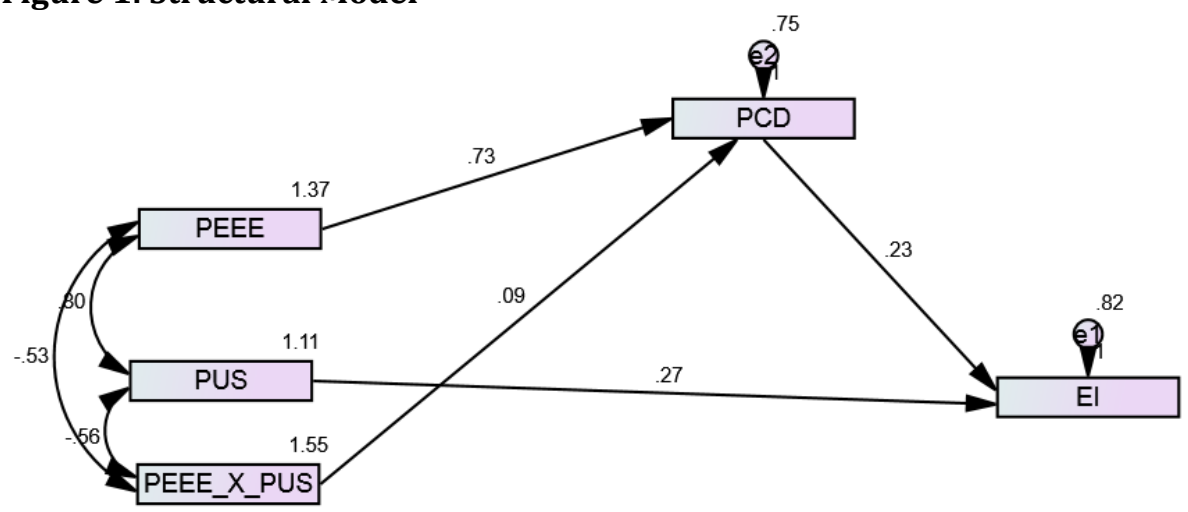

Model Fit (of initial structural model after fitting - i.e., not during moderation tests).

The fitted structural model shows a close fit; in other word it had a very good fit. Table 1 presents the goodness of fit index of the structural model.

Table 1: Goodness of fit for structural model

\begin{tabular}{lll}
\hline Metric & Observed value & Recommended \\
\hline cmin/df & 1.028 & Between 1 and 3 \\
CFI & 1.000 & $>0.950$ \\
RMSEA & .013 & $<0.060$ \\
PCLOSE & .489 & $>0.050$ \\
SRMR & .021 & $<0.090$ \\
\hline
\end{tabular}


Hypothesis testing: All the direct paths in our model were tested after the model fit. In addition, the Mediation was tested using 5000 bias corrected bootstrapping resampling in AMOS. The indirect effect was analysed to establish the mediation. As also earlier pointed out, the independent variables were standardized before creating the product variable to test the interaction hypothesis. The results are summarised in Table 2. Furthermore, we observed that the model fit for the final moderated model was good $(\mathrm{cmin} / \mathrm{df}=.542$; $\mathrm{CFI}=$ 1.000; RMSEA = .000; PCLOSE = .772).

Table 2: Hypothesis Testing Results (Direct and Moderating relationships)

\begin{tabular}{llllll}
\hline Relationship & Estimate & S.E. & C.R. & P & Decision \\
\hline PEEE ---> PCD & .681 & .060 & 11.663 & $* * *$ & Supported \\
PCD ---> EI & .272 & .067 & 3.461 & $* * *$ & Supported \\
PUS ---> EI & .276 & .076 & 3.504 & $* * *$ & Supported \\
PEEE_X_PUS ---> PCD & .093 & .060 & 1.488 & .137 & Not supported \\
\hline
\end{tabular}

$* * * \mathrm{p}<.001$

We found a positive relationship between the perceived effective entrepreneurship education and perceived creativity disposition $(\beta=.681, \mathrm{p}<.001)$. We also observed a direct positive relationship of perceived creativity disposition $(\beta=.272, p<.001)$ and entrepreneurial intention. Furthermore, it is also indicated a direct positive relationship of the perception of university support $(\beta=.276, p<.001)$ with entrepreneurial intention. However, we do not found a positive interactions between the perception of university support and the perceived effective entrepreneurship education to increase intention $(\beta=.093, n s)$.

The mediation test was performed after 5000 bootstrapping in AMOS and the result is presented in Table 3.

Table 3: Standardized Indirect Effects - Two Tailed Significance (BC) (Group number 1 - Default model)

\begin{tabular}{lllll}
\hline & PEEE & PCD & Upper Bounds (BC) & Lower Bounds (BC) \\
\hline PCD & $\ldots$ & $\ldots$ & 0 & 0 \\
EI & 0.000 & $\ldots$ & 0.319 & 0.083 \\
\hline
\end{tabular}

The results indicate that perceived creativity disposition mediates the positive relationship between perceived effective entrepreneurship education and entrepreneurial intention.

\section{Discussion}

Entrepreneurial intention is an important factor for providing good predictive power for engaging in entrepreneurship (Ajzen, 1987; Brush et al., 2008; Kolvereid \& Isaksen, 2006; Shook et al., 2003). This study investigates the interplay among effectiveness of entrepreneurship education and individual characteristic as well as environmental support that have received less attention in entrepreneurship research: perceived creativity disposition and perception of university support. Hence, the study considers how the perception of university support might affect the potency in which student's perceived effectiveness of entrepreneurship education will influence the perception of their creativity disposition on one hand, and how the perception of this creativity disposition will explain the student's perception of effectiveness of the entrepreneurship education on the other hand. We, therefore, argue that entrepreneurial knowledge with environmental support will motivate students to believe they possess the ability to undertake entrepreneurial activity. Our results indicate empirical support for most of our expectations. We found that there is a positive relationship between perceived effective entrepreneurship education and perceived creativity disposition. The study also indicates a positive relationship between perceived creativity disposition and entrepreneurial intention. University support has a direct positive relationship with entrepreneurial intention. Furthermore, perceived creativity disposition mediates the positive relationship between perceived effective entrepreneurship education and entrepreneurial intention. However, the positive interactions proposed between the perceptions of university support and perceived effective entrepreneurship education was not upheld. 
This results support previous research about the relationships in our model. For example, creativity enhancing training was found to significantly improve university students' ability to think creatively (DeTienne \& Chandler, 2004; Feng, 2013), while creative ability of students is also believed to be a motivator of entrepreneurial intention (Fatoki, 2010; Zampetakis et al., 2011). Previous studies have also indicated that support factors in an entrepreneurship setting can influence entrepreneurial intention (see Lüthje \& Franke, 2003; Schwarz et al., 2009; Turker \& Selcuk, 2009). Finally, self-efficacy is shown to be a mechanism that can translate the effect of entrepreneurship programmes on entrepreneurial intention (Souitaris et al., 2007; Zainuddin \& Rejab, 2010). This study offers some important practical implications. Our consideration of the interplay between effectiveness of entrepreneurship education and individual characteristic as well as environmental support shows that these factors should be considered simultaneously to better understand entrepreneurial intention formation. Entrepreneurship programmes in universities should recognise that career-specific skills development as well as structural support from the university management will work together to have effects on the development of students interest to start their own business. In addition, educators should understand that their high involvement in creativity training programmes will make it effective. Moreover, it is also important that the assessment of this training programme allow for individual student's self-assessment of their creativity disposition, as individuals understand themselves better when it comes to their own creative ability (Batey \& Furnham, 2008). This allows the instructors to judge the level of the capability of the students in generating new and valuable ideas necessary to succeed as entrepreneurs. University should also recognize it role as promoters of entrepreneurship, and thus, should provide entrepreneurship education and complimentary supports that are necessary to boost the potential intentions of venture creation. Owing also to the fact that delivery of high quality entrepreneurship programs will result to emergence of higher number of entrepreneurs (Wang \& Verzat, 2011). Hence, this study has clarified more on the interplay between personal and contextual/environmental factors, as little is known about the interaction between university environment and personality.

\section{References}

Ajzen, I. (1987). Attitudes, traits, and actions: Dispositional prediction of behavior in personality and social psychology. Advances in experimental social psychology, 20(1), 63.

Ajzen, I. (1991). The theory of planned behavior. Organizational behavior and human decision processes, 50, 179-211.

Almog-Bareket, G. (2011). The missing component in MBA programs. Management Decision, 49(10), 16001611.

Amabile, T. M. (1996). Creativity and innovation in organizations: Harvard Business School.

Ariff, A. H. M., Bidin, Z., Sharif, Z. \& Ahmad, A. (2010). Predicting entrepreneurship intention among Malay University Accounting students in Malaysia. UNIFAR e-journal, 6(1).

Autio, E., Keeley, R. H., Klofsten, M. \& Ulfstedt, T. (1997). Entrepreneurial intent among students: testing an intent model in Asia, Scandinavia and USA.

Ayob, A., Hussain, A., Mustafa, M. M. \& Shaarani, M. F. A. S. (2011). Nurturing creativity and innovative thinking through experiential learning. Procedia-Social and Behavioral Sciences, 18, 247-254.

Ayobami, A. \& Ofoegbu, O. E. (2011). An examination of the influence of some selected situational factors on entrepreneurial intentions in Nigeria. International Business and Management, 3, 189-196.

Bakotić, D. \& Kružić, D. (2010). Students' perceptions and intentions towards entrepreneurship: The empirical findings from Croatia. The Business Review, 14(2), 209-215.

Batey, M. \& Furnham, A. (2008). The relationship between measures of creativity and schizotypy. Personality and Individual Differences, 45, 816-821.

Baumol, W. J. (2004). Education for innovation: entrepreneurial breakthroughs vs. corporate incremental improvements: National Bureau of Economic Research (NBER) Working Paper 10578.

Bechard, J. P. \& Toulouse, J. M. (1998). Validation of a didactic model for the analysis of training objectives in entrepreneurship. Journal of Business Venturing, 13, 317-332.

Benjamin, L. (1984). Creativity and Counseling. Highlights: An ERIC/CAPS Fact Sheet (ED 260369). Ann Arbor: School of Education, University of Michigan.

Bird, B. (1988). Implementing entrepreneurial ideas: The case for intention. Academy of management Review, $13,442-453$. 
Brandstätter, H. (1997). Becoming an entrepreneur-a question of personality structure? Journal of Economic Psychology, 18, 157-177.

Brush, C. G., Manolova, T. S. \& Edelman, L. F. (2008). Properties of emerging organizations: An empirical test. Journal of Business Venturing, 23, 547-566.

Byabashaija, W., \& Katono, I. (2011). The impact of college entrepreneurial education on entrepreneurial attitudes and intention to start a business in Uganda. Journal of Developmental Entrepreneurship, 16, 127-144. doi: 10.1142/s1084946711001768

Chen, A., Li, L., Li, X., Zhang, J., \& Dong, L. (2013). Study on Innovation Capability of College Students Based on Extenics and Theory of Creativity. Procedia Computer Science, 17, 1194-1201.

Chen, C. T., Hu, J. L., Wang, C. C. \& Chen, C. F. (2011). A study of the effects of internship experiences on the behavioural intentions of college students majoring in leisure management in Taiwan. Journal of Hospitality Leisure Sport \& Tourism Education, 10(2), 61-73.

Chen, Y. F. \& Lai, M. C. (2010). Factors influencing the entrepreneurial attitude of Taiwanese tertiary-level business students. Social Behavior and Personality: an international journal, 38(1), 1-12.

Craft, A. (2001). An analysis of research and literature on creativity in education. Qualifications and Curriculum Authority, 1-37.

Cropley, D. H. \& Cropley, A. J. (2000). Fostering creativity in engineering undergraduates. High ability studies, 11, 207-219.

Darini, M., Pazhouhesh, H. \& Moshiri, F. (2011). Relationship between employee's innovation (creativity) and time management. Procedia - Social and Behavioral Sciences, 25, 201-213. doi: 10.1016/j.sbspro.2011.10.541

Davidsson, P. (1995). Determinants of entrepreneurial intentions. Paper prepared for the RENT IX Workshop, Piacenza, Italy, 3, 23-24.

de Pillis, E. \& Reardon, K. K. (2007). The influence of personality traits and persuasive messages on entrepreneurial intention: a cross-cultural comparison. Career Development International, 12, 382396.

DeTienne, D. R. \& Chandler, G. N. (2004). Opportunity identification and its role in the entrepreneurial classroom: A pedagogical approach and empirical test. Academy of Management Learning \& Education, 3, 242-257.

Dewett, T. \& Gruys, M. L. (2007). Advancing the case for creativity through graduate business education. Thinking Skills and Creativity, 2(2), 85-95.

Dohse, D. \& Walter, S. G. (2010). The role of entrepreneurship education and regional context in forming entrepreneurial intentions: Document de treball de l'IEB.

Drucker, P. F. (1993). The innovation and the entrepreneurial system. Editura Enciclopedic, București.

Edelman, L. \& Yli-Renko, H. (2010). The Impact of environment and entrepreneurial perceptions on venturecreation efforts: Bridging the discovery and creation views of entrepreneurship. Entrepreneurship Theory and Practice, 34, 833-856. doi: 10.1111/j.1540-6520.2010.00395.x

Fatoki, 0. 0. (2010). Graduate entrepreneurial intention in South Africa: motivations and obstacles. International Journal of Business and Management, 5(9), P87.

Fayolle, A. (2000). Exploratory study to assess the effects of entrepreneurship programs on French student entrepreneurial behaviors. Journal of Enterprising Culture, 8, 169-184.

Feng, H. Y. (2013). A Case Study on Creativity, Innovation and Entrepreneurship Education of the University in Taiwan. Paper presented at the Active Citizenship by Knowledge Management \& Innovation: Proceedings of the Management, Knowledge and Learning International Conference 2013.

Fitzsimmons, J. R. \& Douglas, E. J. (2011). Interaction between feasibility and desirability in the formation of entrepreneurial intentions. Journal of Business Venturing, 26, 431-440. doi: 10.1016/j.jbusvent.2010.01.001

Franke, N. \& Lüthje, C. (2004). Entrepreneurial intentions of business students-a benchmarking study. International Journal of Innovation and Technology Management, 1, 269-288.

Fritsch, M. \& Sorgner, A. (2013). Entrepreneurship and creative professions: A micro-level analysis: SOEPpapers on Multidisciplinary Panel Data Research.

Ghosh, K. (2014). Creativity in Business Schools: Towards a Need Based Developmental Approach. Global Journal of Flexible Systems Management, 15(2), 169-178. 
Gibb, A. (2002). In pursuit of a new 'enterprise'and 'entrepreneurship'paradigm for learning: creative destruction, new values, new ways of doing things and new combinations of knowledge. International Journal of Management Reviews, 4, 233-269.

Gibb, A. A. (1993). Enterprise Culture and Education Understanding Enterprise Education and Its Links with Small Business, Entrepreneurship and Wider Educational Goals. International Small Business Journal, 11(3), 11-34.

Godfrey, A. B. (1996). Creativity, innovation and quality. Quality Digest, 16(12), 17.

Gurbuz, G. \& Aykol, S. (2008). Entrepreneurial intentions of young educated public in Turkey. Journal of Global Strategic Management, 4(1), 47-56.

Hamidi, D. Y., Wennberg, K. \& Berglund, H. (2008). Creativity in entrepreneurship education. Journal of Small Business and Enterprise Development, 15, 304-320. doi: 10.1108/14626000810871691

Jones, C. \& English, J. (2004). A contemporary approach to entrepreneurship education. Education + Training, 46, 416-423. doi: 10.1108/00400910410569533

Kautonen, T., Luoto, S. \& Tornikoski, E. T. (2010). Influence of work history on entrepreneurial intentions in 'prime age'and 'third age': A preliminary study. International Small Business Journal, 28, 583-601.

Keat, O. Y., Selvarajah, C. \& Meyer, D. (2011). Inclination towards entrepreneurship among university students: An empirical study of Malaysian university students. International Journal of Business and Social Science, 2, 206-220.

Kirby, D. A. (2006). Creating entrepreneurial universities in the UK: Applying entrepreneurship theory to practice. The Journal of Technology Transfer, 31, 599-603.

Kolvereid, L. \& Isaksen, E. (2006). New business start-up and subsequent entry into self-employment. Journal of Business Venturing, 21, 866-885.

Krueger Jr, N. F., Reilly, M. D. \& Carsrud, A. L. (2000). Competing models of entrepreneurial intentions. Journal of Business Venturing, 15, 411-432.

Lee, L., Wong, P. K., Foo, M. D. \& Leung, A. (2011). Entrepreneurial intentions: The influence of organizational and individual factors. Journal of Business Venturing, 26, 124-136. doi: 10.1016/j.jbusvent.2009.04.003

Liñán, F. \& Chen, Y. W. (2009). Development and cross-cultural application of a specific instrument to measure entrepreneurial intentions. Entrepreneurship Theory and Practice, 33, 593-617.

Lüthje, C. \& Franke, N. (2003). The 'making'of an entrepreneur: testing a model of entrepreneurial intent among engineering students at MIT. R\&d Management, 33, 135-147.

Maina, R. W. (2011). Determinants of entrepreneurial intentions among Kenyan college graduates. KCA Journal of Business Management, 3(2).

Mitchel, J. O. (1981). The effect of intentions, tenure, personal, and organizational variables on managerial turnover. Academy of Management journal, 24, 742-751.

Morris, M. H., \& Lewis, P. S. (1995). The determinants of entrepreneurial activity: implications for marketing. European journal of marketing, 29(7), 31-48.

OECD. (2010). University entrepreneurship support: Policy issues, good practices and recommendations. Working Paper: OECD Local Economic and Employment Development (LEED)

Palich, L. E. \& Ray Bagby, D. (1995). Using cognitive theory to explain entrepreneurial risk-taking: Challenging conventional wisdom. Journal of Business Venturing, 10, 425-438.

Peterman, N. E. \& Kennedy, J. (2003). Enterprise education: Influencing students' perceptions of entrepreneurship. Entrepreneurship Theory and Practice, 28, 129-144.

Pittaway, L., Hannon, P., Gibb, A. \& Thompson, J. (2009). Assessment practice in enterprise education. International Journal of Entrepreneurial Behaviour \& Research, 15(1), 71-93.

Robinson, P. \& Haynes, M. (1991). Entrepreneurship education in America's major universities. Entrepreneurship Theory and Practice, 15(3), 41-52.

Romero, I., Petrescu, R. M. \& Balalia, A. E. (2011). Universities as suppliers of entrepreneurship education services. The Cases of the university of Seville and the academy of economic Studies in Bucharest. the amfiteatru economic journal, 13, 347-361.

Runco, M. A. (2004). Everyone Has Creative Potential. In Sternberg, R.J., Grigorenko, E.L. \& Singer, J.L. (Eds). Creativity: From potential to realisation (pp: 21-30). Wahington, DC: American Psychology Association. 
Schwarz, E. J., Wdowiak, M. A., Almer-Jarz, D. A. \& Breitenecker, R. J. (2009). The effects of attitudes and perceived environment conditions on students' entrepreneurial intent: An Austrian perspective. Education + Training, 51, 272-291. doi: 10.1108/00400910910964566

Segal, G., Borgia, D. \& Schoenfeld, J. (2005). The motivation to become an entrepreneur. International Journal of Entrepreneurial Behaviour \& Research, 11(1), 42-57.

Shapero, A., \& Sokol, L. (1982). The social dimensions of entrepreneurship. Encyclopedia of entrepreneurship, 2, 72-90.

Shook, C. L., Priem, R. L. \& McGee, J. E. (2003). Venture creation and the enterprising individual: A review and synthesis. Journal of Management, 29, 379-399.

Souitaris, V., Zerbinati, S. \& Al-Laham, A. (2007). Do entrepreneurship programmes raise entrepreneurial intention of science and engineering students? The effect of learning, inspiration and resources. Journal of Business Venturing, 22, 566-591. doi: 10.1016/j.jbusvent.2006.05.002

Tajeddini, K. \& Mueller, S. L. (2009). Entrepreneurial characteristics in Switzerland and the UK: A comparative study of techno-entrepreneurs. Journal of International Entrepreneurship, 7(1), 1-25.

Tepper, S. J. \& Kuh, G. D. (2011). Let's get serious about cultivating creativity. Chronicle of Higher Education.

Tubbs, M. E. \& Ekeberg, S. E. (1991). The role of intentions in work motivation: Implications for goal-setting theory and research. Academy of management Review, 16, 180-199.

Turker, D. \& Selcuk, S. S. (2009). Which factors affect entrepreneurial intention of university students? Journal of European Industrial Training, 33, 142-159. doi: 10.1108/03090590910939049

Wang, Y. \& Verzat, C. (2011). Generalist or specific studies for engineering entrepreneurs?: Comparison of French engineering students' trajectories in two different curricula. Journal of Small Business and Enterprise Development, 18, 366-383. doi: 10.1108/14626001111127124

Williamson, B. (2001). Creativity, the corporate curriculum and the future: a case study. Futures, 33(6), 541555.

Wilson, F., Kickul, J. \& Marlino, D. (2007). Gender, entrepreneurial self efficacy, and entrepreneurial career intentions: Implications for entrepreneurship education. Entrepreneurship Theory and Practice, 31, 387-406.

Zainuddin, M. N. \& Rejab, M. R. M. (2010). Assessing “ME generation's” entrepreneurship degree programmes in Malaysia. Education + Training, 52, 508-527. doi: 10.1108/00400911011068469

Zampetakis, L. A., Gotsi, M., Andriopoulos, C. \& Moustakis, V. (2011). Creativity and entrepreneurial intention in young people: Empirical insights from business school students. The International Journal of Entrepreneurship and Innovation, 12, 189-199. doi: 10.5367/ijei.2011.0037

Zhou, J. \& George, J. M. (2001). When job dissatisfaction leads to creativity: Encouraging the expression of voice. Academy of Management journal, 44, 682-696. 